\title{
A Multi-Omics Analysis of PON1 Lactonase Activity in Relation to Human Health and Disease
}

\author{
Boštjan Petrič, ${ }^{1}$ Tanja Kunej, ${ }^{2}$ and Aljoša Bavec ${ }^{1}$
}

\begin{abstract}
Paraoxonase 1 (PON1) enzyme has antioxidative properties and is present in mammalian blood and several other body fluids. In blood, PON1 is usually integrated into the high-density lipoprotein (HDL) cholesterol. PON1 is a highly versatile enzyme displaying diverse functions such as arylesterase, lactonase, and paraoxonase, among others. PON1 activities are usually investigated with artificial substrates, for example, dihydrocoumarin and thiobutyl butyrolactone for lactonase activity. The PON1 enzyme activities measured with different substrates tend to be falsely assumed as being equivalent in the literature, although there are poor or weak correlations among the PON1 enzyme activities with different substrates. In addition, and despite our knowledge of the factors influencing PON1 paraoxonase and arylesterase activities, there is little knowledge of PON1 lactonase activity variations and attendant mechanisms. This is important considering further that the lactonase activity is the native activity of PON1. We report here a multi-omics analysis of PON1 lactonase activity. The influence of genetic variations, particularly of single nucleotide polymorphisms and epigenetic, proteomic, and lipidomic variations on PON1 lactonase activity are reviewed. In addition, the influence of various environmental, clinical, and demographic variables on PON1 lactonase activity is discussed. Finally, we examine the associations between PON1 lactonase activity and health states and common complex diseases such as atherosclerosis, dementias, obesity, and diabetes. To the best of our knowledge, this is the first multi-omics analysis of PON1 lactonase activity with an eye to future applications in basic life sciences and translational medicine and the nuances of critically interpreting PON1 function with lactones as substrates.
\end{abstract}

Keywords: paraoxonase 1, multi-omics, lactonase, genomics, proteomics, atherosclerosis, dementias, obesity, diabetes

\section{Introduction}

$\mathbf{N}$ UMEROUS ARTICLES HAVE BEEN PUBLISHED in the last decades about serum paraoxonase 1 (PON1), an enzyme found in different mammal species and other animals, including fishes, amphibians, and birds, and its association with various medical conditions in humans. Various biological and environmental/social factors can influence PON1 expression and activity.

The association between PON1 and medical conditions is usually investigated with three most common approaches: (1) genotyping of single nucleotide polymorphisms (SNPs), (2) quantification of enzyme in a biological sample, and (3) measurement of enzymatic activity of PON1 as determined using different substrates (Ceron et al., 2014). Gene polymorphisms, enzyme quantity, and enzyme activity are dif- ferent parameters that may or may not correlate with each other (Costa et al., 2005); however, it is less well understood that different enzymatic activities of PON1 may or may not correlate with each other as well.

The three main activities of PON1 are aryldialkylphosphatase, more commonly known as paraoxonase activity, arylesterase and lactonase activity (Harel et al., 2004). Each of these can be investigated with several different artificial substrates (Khersonsky and Tawfik, 2005); however, the exact physiological substrates of PON1 are poorly understood. In Figure 1, the structure of the most commonly used substrate for each of the three main activities is displayed. A possible candidate for a physiological substrate is homocysteine thiolactone, which is a known risk factor in atherosclerotic vascular diseases; however, PON1 has rather low thiolactonase activity (Aharoni et al., 2004).

\footnotetext{
${ }^{1}$ Institute of Biochemistry and Molecular Genetics, Faculty of Medicine, University of Ljubljana, Ljubljana, Slovenia.

${ }^{2}$ University of Ljubljana, Biotechnical Faculty, Department of Animal Science, Domžale, Slovenia.

(C) Boštjan Petrič, et al., 2020. Published by Mary Ann Liebert, Inc. This Open Access article is distributed under the terms of the Creative Commons Attribution Noncommercial License (http://creative commons.org/licenses/by-nc/4.0/) which permits any noncommercial use, distribution, and reproduction in any medium, provided the original author(s) and the source are credited.
} 


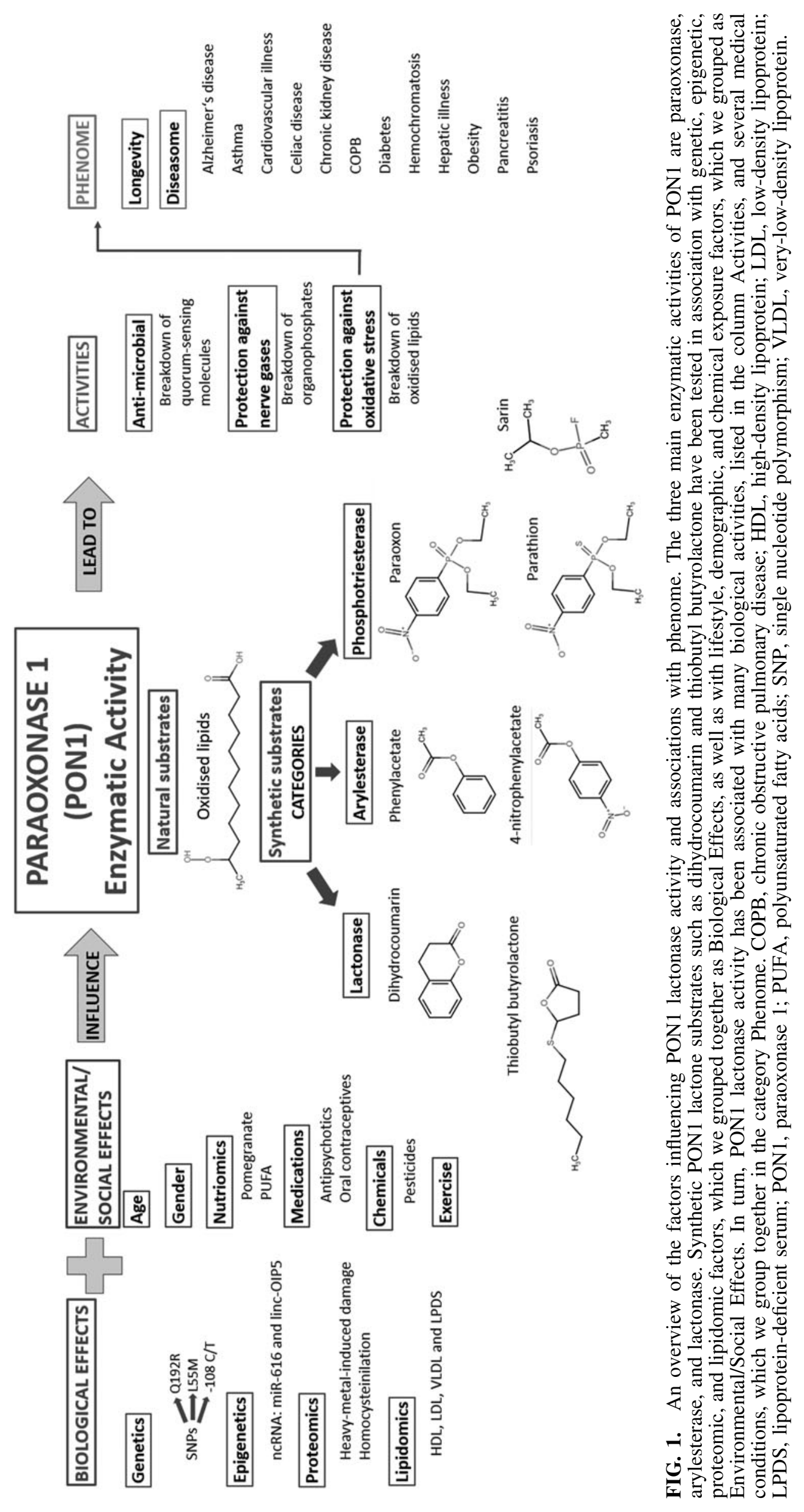


Paraoxonase activity is unlikely to be a native activity of PON1, as organophosphates are uncommon in nature (Khersonsky and Tawfik, 2005; Metcalf and Bruno, 2016). Structure-reactivity studies suggest that the primary function of PON1 in terms of evolutionary development is lactonase activity (Khersonsky and Tawfik, 2005). Especially paraoxonase activity is often poorly correlated with the other two enzymatic activities (Gugliucci et al., 2015; Kowalska et al., 2018; Martinelli et al., 2013; Romani et al., 2009; Rosenblat et al., 2006). Thus, the experimental results of PON1 can be grouped by enzymatic activity and those research articles in which the same activity has been investigated, preferably with the same substrate, can be compared.

An extensive review on paraoxonase and arylesterase activities has already been published (Dardiotis et al., 2019). However, the literature lacks analyses on PON1's native (lactonase) activity. Although different research groups have focused on SNP variation in the PON1 gene and its association with enzymatic activity (Dardiotis et al., 2019; Darney et al., 2020), factors besides genotype may also influence the enzymatic activity of PON1. Hence, in this study, we examine different -omics levels that have been associated specifically with the lactonase activity of PON1. This article is the first to specifically address and review the lactonase activity of PON1.

In this analysis, we also examine and synthesize the associations between various medical conditions and the lactonase activity of PON1. As PON1 has antioxidative activity, its lactonase activity may be correlated with oxidative stressand inflammation-related diseases, primarily those associated with aging. Indeed PON1 activity is shown to be associated with neurodegenerative and cardiovascular diseases (CVDs), as well as diabetes, cancer, and other disorders (Shunmoogam et al., 2018).

Most of the research on PON1 lactonase activity has been performed on humans; however, some research groups also investigated lactonase activity in mice, rats, and cows (Farid et al., 2013; Kopál et al., 2014; Romani et al., 2009; Zhang et al., 2010). A number of studies also focused on recombinant variants of PON1 (rePON1). Because rePON1 variants, unlike native PON1, are water soluble, they are preferred instead of native PON1 for the investigation of general properties of paraoxonases and for biotechnological applications. However, these investigations are not included in this study because they are of limited relevance to this article's focus on biological influences of PON1 activity, and on PON1's influence on the phenome in turn.

The two most common lactone substrates used on PON1 are dihydrocoumarin (DHC) and thiobutyl butyrolactone (TBBL), which have been cited in at least 100 research articles. We included both of these substrates in this study. Another commonly used substrate is homocystein thiolactone (HcyTL), which is usually treated separately as the main determinant of thiolactonase activity, and hence is omitted in this review. We included several less common substrates, which should be considered by future researchers as alternatives to existing substrates. Among these less common substrates are $\delta$-valerolactone, $\gamma$-thiobutyrolactone (TBL) and benzopyran-2-one.

The activity of an enzyme depends on both its amount and its affinity for a substrate. Some of the factors discussed in this article (e.g., variations in the promoter sequence of the PON1 gene) are likely to primarily affect the amount of
PON1 that is present in an organism, whereas others (e.g., the presence of drugs interacting with PON1 in the bloodstream) are likely to primarily influence PON1's affinity for its substrates. Because almost all the studies cited in this article used specific activity as the only measure of PON1 lactonase activity, it is usually not possible to disentangle these two components.

\section{Materials and Methods}

This study and analysis were conducted using publicly available biomedical literature and hence, no institutional research ethics committee approval was required. We performed a screening of Google Scholar, Embase, and PubMed databases with the keywords: PON1, paraoxonase 1, TBBL, TBL, DHC, dihydrocoumarin, valerolactone, and the combinations of these. We also searched the references of all the articles thus obtained for additional articles that might discuss PON1 lactonase activity. We limited ourselves to full articles, written in English and published in peer-reviewed journals. The screening was performed for articles published between January 2000 and July 2020 and the publications obtained were published between January 2006 and June 2020.

It has been emphasized that in any study investigating PON1 activity, cases and controls should be matched for PON1 haplotype, as the amount of PON1 activity is mainly determined by SNP distribution (Mackness and Mackness, 2015). As the overall number of articles dealing with lactonase PON1 activity is limited, this criterion could not be fulfilled in this analysis, which is structured according to the omics taxonomy proposed previously (Pirih and Kunej, 2017).

\section{Results and Discussion}

\section{Overview of the effects on PON1 activity}

The 46 articles that we included in the study are listed, along with the omics category they discussed and the substrate used in the article, in Table 1 . Of the 46 articles in question, 17 discuss the various effects on PON1 lactonase activity.

Biological effects on PON1 activity. The structure of the article and the graphical overview of the topics summarized are given in Figure 1. The influences of genetics, epigenetics, proteomics, and the lipid environment of PON1 were grouped together as "biological" effects. Almost all the investigations within this category have been performed on humans. The most thoroughly studied influence on PON1 activity has been that of genetics, followed by molecular environment. The latter is particularly connected to the lipids and proteins that together compose high-density lipoprotein (HDL) particles and associate with PON1 protein.

Genetics/genomics. The two most frequently reported polymorphisms on the human PON1 gene are SNPs that change the amino acid sequence of PON1, rs662 and rs854560, also referred to as Q192R and L55M, respectively (Shunmoogam et al., 2018). There is one more SNP in the coding region of $P O N 1$, rs 13306698 or R160G, with a rather low minor allele frequency of $0.02-0.11$; there are no studies investigating it in connection with PON1 lactonase activity. There are also several other SNPs present either in 
Table 1. A List of the Research Articles Describing Lactonase Activity That Were Included in Our Analysis, with the Area That Was Investigated in Association with PON1 Lactonase Activity, and the Lactone Substrate, Specified for Each of the Articles

\begin{tabular}{|c|c|c|c|c|}
\hline & Reference & Title & $\begin{array}{l}\text { Area }(s) \\
\text { investigated }\end{array}$ & $\begin{array}{l}\text { Substrate }(s) \\
\quad \text { used }\end{array}$ \\
\hline 1 & $\begin{array}{l}\text { Alaminos- } \\
\text { Castillo et al. } \\
(2019)\end{array}$ & $\begin{array}{l}\text { Increased PON lactonase activity in morbidly obese } \\
\text { patients is associated with impaired lipid profile }\end{array}$ & Obesity & DHC \\
\hline 2 & $\begin{array}{l}\text { Aviram and } \\
\text { Rosenblat } \\
\text { (2012) }\end{array}$ & Pomegranate protection against cardiovascular diseases & Nutriomics & $\mathrm{DHC}$ \\
\hline 3 & $\begin{array}{l}\text { Bacchetti et al. } \\
\quad(2015)\end{array}$ & $\begin{array}{l}\text { Higher levels of oxidized low density lipoproteins in } \\
\text { Alzheimer's disease patients: Roles for platelet } \\
\text { activating factor acetyl hydrolase and } \\
\text { paraoxonase-1 }\end{array}$ & $\begin{array}{l}\text { Alzheimer's } \\
\text { disease }\end{array}$ & $\mathrm{DHC}$ \\
\hline 4 & $\begin{array}{l}\text { Bacchetti et al. } \\
\text { (2019) }\end{array}$ & $\begin{array}{l}\text { HDL functionality in follicular fluid in normal weight } \\
\text { and obese women undergoing assisted reproductive } \\
\text { treatment }\end{array}$ & Obesity & $\mathrm{DHC}$ \\
\hline 5 & $\begin{array}{l}\text { Bacchetti et al. } \\
\quad(2020)\end{array}$ & $\begin{array}{l}\text { Plasma oxidation status and antioxidant capacity in } \\
\text { psoriatic children }\end{array}$ & Psoriasis & $\mathrm{DHC}$ \\
\hline 6 & $\begin{array}{l}\text { Bains et al. } \\
\quad(2019)\end{array}$ & $\begin{array}{l}\text { Paraoxonase 1, HDL subclasses and postsurgery acute } \\
\text { inflammation: A pilot study }\end{array}$ & Obesity & $\mathrm{DHC}$ \\
\hline 7 & $\begin{array}{l}\text { Cervellati et al. } \\
\quad(2018)\end{array}$ & $\begin{array}{l}\text { Paraoxonase, arylesterase and lactonase activities of } \\
\text { paraoxonase-1 (PON1) in obese and severely obese } \\
\text { women }\end{array}$ & Obesity & TBL \\
\hline 8 & Chen et al. (2018) & $\begin{array}{l}\text { Influences of PON1 on airway inflammation and } \\
\text { remodeling in bronchial asthma }\end{array}$ & Asthma & $\mathrm{DHC}$ \\
\hline 9 & Chen et al. (2020) & $\begin{array}{l}\text { Linc-OIP5 working as a ceRNA of miR- } 616 \text { promotes } \\
\text { PON1 expression in HUEVC cells }\end{array}$ & Epigenetics & $\mathrm{DHC}$ \\
\hline 10 & $\begin{array}{l}\text { Craciun et al. } \\
\text { (2016) }\end{array}$ & $\begin{array}{l}\text { Paraoxonase- } 1 \text { activities in children and adolescents } \\
\text { with type } 1 \text { diabetes mellitus }\end{array}$ & Diabetes & $\delta$-valerolactone \\
\hline 11 & $\begin{array}{l}\text { De Keyzer et al. } \\
\text { (2009) }\end{array}$ & $\begin{array}{l}\text { Increased PAFAH and oxidized lipids are associated } \\
\text { with inflammation and atherosclerosis in } \\
\text { hypercholesterolemic pigs }\end{array}$ & $\begin{array}{l}\text { Cardiovascular } \\
\text { disease }\end{array}$ & TBBL \\
\hline 12 & Farid et al. (2013) & $\begin{array}{l}\text { Serum paraoxonase- } 1 \text { as biomarker for improved } \\
\text { diagnosis of fatty liver in dairy cows }\end{array}$ & Hepatic illness & $\mathrm{DHC}$ \\
\hline 13 & Ferré et al. (2013) & $\begin{array}{l}\text { Impaired paraoxonase- } 1 \text { status in obese children. } \\
\text { Relationships with insulin resistance and metabolic } \\
\text { syndrome }\end{array}$ & Obesity & TBBL \\
\hline 14 & $\begin{array}{l}\text { Ferretti et al. } \\
\quad(2010)\end{array}$ & $\begin{array}{l}\text { Effect of homocysteinylation on high-density } \\
\text { lipoprotein physicochemical properties }\end{array}$ & Proteomics & $\mathrm{DHC}$ \\
\hline 15 & $\begin{array}{l}\text { Ferretti et al. } \\
\qquad(2012)\end{array}$ & $\begin{array}{l}\text { Lipid peroxidation and paraoxonase- } 1 \text { activity in celiac } \\
\text { disease }\end{array}$ & Celiac disease & $\mathrm{DHC}$ \\
\hline 16 & $\begin{array}{l}\text { Gaidukov and } \\
\text { Tawfik (2007) }\end{array}$ & $\begin{array}{l}\text { The development of human sera tests for HDL-bound } \\
\text { serum PON1 and its lipolactonase activity }\end{array}$ & / & $\begin{array}{l}\text { TBBL, } \\
\text { DEPCyMC }\end{array}$ \\
\hline 17 & Gilca et al. (2014) & $\begin{array}{l}\text { A study of antioxidant activity in patients with } \\
\text { schizophrenia taking atypical antipsychotics }\end{array}$ & Medications & $\mathrm{DHC}$ \\
\hline 18 & $\begin{array}{l}\text { Gugliucci et al. } \\
\text { (2014) }\end{array}$ & $\begin{array}{l}\text { Paraoxonase } 1 \text { lactonase activity and distribution in the } \\
\text { HDL subclasses in the cord blood }\end{array}$ & Age & $\mathrm{DHC}$ \\
\hline 19 & $\begin{array}{l}\text { Gugliucci et al. } \\
\text { (2015) }\end{array}$ & $\begin{array}{l}\text { Low protective PON1 lactonase activity in an Arab } \\
\text { population with high rates of coronary heart disease } \\
\text { and diabetes A }\end{array}$ & $\begin{array}{l}\text { Cardiovascular } \\
\text { disease }\end{array}$ & $\mathrm{DHC}$ \\
\hline 20 & $\begin{array}{l}\text { Hernandez et al. } \\
\quad(2009)\end{array}$ & $\begin{array}{l}\text { Interaction between human serum esterases and } \\
\text { environmental metal compounds }\end{array}$ & Proteomics & $\mathrm{DHC}$ \\
\hline 21 & $\begin{array}{l}\text { Kameyama et al. } \\
\text { (2016) }\end{array}$ & $\begin{array}{l}\text { Postprandial paraoxonase } 1 \text { activity after consumption } \\
\text { of recommended amounts of mixed meals in healthy } \\
\text { men }\end{array}$ & Nutriomics & TBBL \\
\hline 22 & $\begin{array}{l}\text { Kopál et al. } \\
\text { (2014) }\end{array}$ & $\begin{array}{l}\text { Effect of PUFA-rich plant oil on risk factors of } \\
\text { STZ-induced diabetes in Wistar rats }\end{array}$ & Nutriomics & $\mathrm{DHC}$ \\
\hline 23 & $\begin{array}{l}\text { Kowalska et al. } \\
\quad(2018)\end{array}$ & $\begin{array}{l}\text { Influence of oral contraceptives on lipid profile and } \\
\text { paraoxonase and commonly hepatic enzymes } \\
\text { activities }\end{array}$ & Medications & $\mathrm{DHC}$ \\
\hline 24 & $\begin{array}{l}\text { Lozano-Paniagua } \\
\text { et al. (2016) }\end{array}$ & $\begin{array}{l}\text { Activity and determinants of cholinesterases and } \\
\text { paraoxonase- } 1 \text { in blood of workers exposed to } \\
\text { noncholinesterase inhibiting pesticides }\end{array}$ & Chemicals & $\mathrm{DHC}$ \\
\hline
\end{tabular}




\begin{tabular}{|c|c|c|c|c|}
\hline & Reference & Title & $\begin{array}{c}\text { Area }(s) \\
\text { investigated }\end{array}$ & $\begin{array}{l}\text { Substrate(s) } \\
\text { used }\end{array}$ \\
\hline 25 & $\begin{array}{l}\text { Marek et al. } \\
\text { (2018) }\end{array}$ & $\begin{array}{l}\text { Decreases in paraoxonase- } 1 \text { activities promote a } \\
\text { proinflammatory effect of lipids peroxidation } \\
\text { products in nonsmoking and smoking patients with } \\
\text { acute pancreatitis }\end{array}$ & Pancreatitis & DHC \\
\hline 26 & $\begin{array}{l}\text { Marsillach et al. } \\
\text { (2009) }\end{array}$ & $\begin{array}{l}\text { The measurement of the lactonase activity of } \\
\text { paraoxonase- } 1 \text { in the clinical evaluation of patients } \\
\text { with chronic liver impairment }\end{array}$ & Hepatic illness & TBBL \\
\hline 27 & $\begin{array}{l}\text { Martinelli et al. } \\
\text { (2009) }\end{array}$ & $\begin{array}{l}\text { Novel serum paraoxonase activity assays are associated } \\
\text { with coronary artery disease }\end{array}$ & $\begin{array}{l}\text { Cardiovascular } \\
\text { disease }\end{array}$ & $\begin{array}{l}\text { TBBL, } \\
\text { DEPCyMC }\end{array}$ \\
\hline 28 & $\begin{array}{l}\text { Martinelli et al. } \\
\text { (2012) }\end{array}$ & $\begin{array}{l}\text { Low levels of serum paraoxonase activities are } \\
\text { characteristic of metabolic syndrome and may } \\
\text { influence the metabolic-syndrome-related risk of } \\
\text { coronary artery disease }\end{array}$ & $\begin{array}{l}\text { Cardiovascular } \\
\text { disease }\end{array}$ & $\begin{array}{l}\text { TBBL, } \\
\text { DEPCyMC }\end{array}$ \\
\hline 29 & $\begin{array}{l}\text { Martinelli et al. } \\
\text { (2013) }\end{array}$ & $\begin{array}{l}\text { Paraoxonase- } 1 \text { status in patients with hereditary } \\
\text { hemochromatosis }\end{array}$ & Hemochromatosis & TBBL \\
\hline 30 & $\begin{array}{l}\text { Mogarekar and } \\
\text { Talekar (2013) }\end{array}$ & $\begin{array}{l}\text { Serum lactonase and arylesterase activities in alcoholic } \\
\text { hepatitis and hepatitis B }\end{array}$ & Hepatic illness & DHC \\
\hline 31 & $\begin{array}{l}\text { Mohammed et al. } \\
\text { (2019) }\end{array}$ & $\begin{array}{l}\text { Circulating lactonase activity but not protein level of } \\
\text { PON-1 predicts adverse outcomes in subjects with } \\
\text { chronic kidney disease }\end{array}$ & $\begin{array}{l}\text { Chronic kidney } \\
\text { disease }\end{array}$ & $\begin{array}{l}\text { benzopyran- } \\
\text { 2-one }\end{array}$ \\
\hline 32 & $\begin{array}{l}\text { Murillo-González } \\
\text { et al. (2020) }\end{array}$ & $\begin{array}{l}\text { PON1 lactonase activity and its association with } \\
\text { cardiovascular disease }\end{array}$ & $\begin{array}{l}\text { Cardiovascular } \\
\text { disease }\end{array}$ & DHC \\
\hline 33 & $\begin{array}{l}\text { Passaro et al. } \\
\text { (2018) }\end{array}$ & $\begin{array}{l}\text { Distribution of paraoxonase-1 (PON-1) and lipoprotein } \\
\text { phospholipase A2 (Lp-PLA2) across lipoprotein } \\
\text { subclasses in subjects with type } 2 \text { diabetes }\end{array}$ & Diabetes & TBL \\
\hline 34 & $\begin{array}{l}\text { Ponce-Ruiz et al. } \\
\text { (2020) }\end{array}$ & $\begin{array}{l}\text { Phenotypes and concentration of PON1 in } \\
\text { cardiovascular disease: The role of nutrient intake }\end{array}$ & $\begin{array}{l}\text { Cardiovascular } \\
\text { disease }\end{array}$ & DHC \\
\hline 35 & $\begin{array}{l}\text { Quillen et al. } \\
\text { (2012) }\end{array}$ & $\begin{array}{l}\text { Novel associations of nonstructural loci with } \\
\text { paraoxonase activity }\end{array}$ & $\begin{array}{l}\text { Age, gender, } \\
\text { genomics }\end{array}$ & DHC \\
\hline 36 & $\begin{array}{l}\text { Rainwater et al. } \\
\text { (2009) }\end{array}$ & $\begin{array}{l}\text { Determinants of variation in human serum paraoxonase } \\
\text { activity }\end{array}$ & Genomics & DHC \\
\hline 37 & Rock et al. (2008) & $\begin{array}{l}\text { Consumption of Wonderful variety pomegranate juice } \\
\text { and extract by diabetic patients increases } \\
\text { paraoxonase } 1 \text { association with high-density } \\
\text { lipoprotein and stimulates its catalytic activities }\end{array}$ & Nutriomics & DHC, TBBL \\
\hline 38 & $\begin{array}{l}\text { Romani et al. } \\
\text { (2009) }\end{array}$ & $\begin{array}{l}\text { Modulation of paraoxonase } 1 \text { and } 3 \text { expression after } \\
\text { moderate exercise training in the rat }\end{array}$ & Exercise & $\begin{array}{l}\text { DHC, } \\
\text { 2-coumaranone }\end{array}$ \\
\hline 39 & $\begin{array}{l}\text { Rosenblat et al. } \\
\text { (2006) }\end{array}$ & $\begin{array}{l}\text { Paraoxonase } 1 \text { (PON1) is a more potent antioxidant and } \\
\text { stimulant of macrophage cholesterol efflux, when } \\
\text { present in HDL than in lipoprotein-deficient serum: } \\
\text { Relevance to diabetes }\end{array}$ & Lipidomics & DHC \\
\hline 40 & $\begin{array}{l}\text { Rosenblat et al. } \\
\text { (2012) }\end{array}$ & $\begin{array}{l}\text { VLDL triglycerides inhibit HDL-associated } \\
\text { paraoxonase } 1 \text { (PON1) activity: In vitro and in vivo } \\
\text { studies }\end{array}$ & Lipidomics & DHC \\
\hline 41 & $\begin{array}{l}\text { Rupérez et al. } \\
\text { (2013) }\end{array}$ & $\begin{array}{l}\text { Paraoxonase } 1 \text { activities and genetic variation in } \\
\text { childhood obesity }\end{array}$ & Obesity & DHC \\
\hline 42 & $\begin{array}{l}\text { Russo et al. } \\
\text { (2018) }\end{array}$ & $\begin{array}{l}\text { An intensive lifestyle intervention reduces circulating } \\
\text { oxidized low-density lipoprotein and increases } \\
\text { human paraoxonase activity in obese subjects }\end{array}$ & Exercise & DHC \\
\hline 43 & Soler et al. (2013) & $\begin{array}{l}\text { Paraoxonase- } 1 \text { is associated with corneal endothelial } \\
\text { cell alterations in patients with chronic obstructive } \\
\text { pulmonary disease }\end{array}$ & $\begin{array}{l}\text { Chronic obstructive } \\
\text { pulmonary } \\
\text { disease }\end{array}$ & TBBL \\
\hline 44 & $\begin{array}{l}\text { Zhang et al. } \\
\text { (2010) }\end{array}$ & $\begin{array}{l}\text { Studies on protective effects of human paraoxonases } 1 \\
\text { and } 3 \text { on atherosclerosis in apolipoprotein E } \\
\text { knockout mice }\end{array}$ & $\begin{array}{l}\text { Cardiovascular } \\
\text { disease }\end{array}$ & DHC \\
\hline 45 & $\begin{array}{l}\text { Zhou et al. } \\
\text { (2020a) }\end{array}$ & $\begin{array}{l}\text { Lactonase activity, status, and genetic variations of } \\
\text { paraoxonase } 1 \text { in women with gestational diabetes } \\
\text { mellitus }\end{array}$ & Diabetes & $\begin{array}{l}\text { TBBL, } \\
\text { DEPCyMC }\end{array}$ \\
\hline 46 & $\begin{array}{l}\text { Zhou et al. } \\
\text { (2020b) }\end{array}$ & $\begin{array}{l}\text { Lactonase activity and status of paraoxonase } 1 \text { and } \\
\text { oxidative stress in neonates of women with } \\
\text { gestational diabetes mellitus }\end{array}$ & Diabetes & $\begin{array}{l}\text { TBBL, } \\
\text { DEPCyMC }\end{array}$ \\
\hline
\end{tabular}

DEPCyMC, 7-O-diethyl phosphoryl,3-cyano,4-methyl,7-hydroxycoumarin; DHC, 3,4-dihydrocoumarin; PON1, paraoxonase 1; TBBL, thiobutyl butyrolactone; TBL, $\gamma$-thiobutyrolactone. 
introns or the promoter region of $P O N 1$, of which the best known is rs 705379 (also referred as $-107 \mathrm{C} / \mathrm{T}$ or $-108 \mathrm{C} / \mathrm{T}$ ) (Shunmoogam et al., 2018).

Two different articles provided numbers for the percentage of variation of activity that is explained by each of the main parameters, such as genetic variations and sex, affecting PON1 lactonase activity (Quillen et al., 2012; Rainwater et al., 2009). Rainwater et al. analyzed 922 participants using three different substrates, including DHC. The parameters investigated were grouped into three categories: metabolic, lifestyle, and genetic. The genetic factors explained $67 \%$ of all the observed interindividual variation, of which $47 \%$ of the variation was traced back to chromosome 7 , on which the PON1 gene is located (Rainwater et al., 2009).

Quillen et al. (2012) reported 767 individuals and provided information about genetic influences on activity levels for paraoxon, phenyl acetate, and DHC. Five loci on chromosomes 3, 4, and 17 explained $7.8 \%$ of genetic variation in PON1 activity where lactone was used as a substrate. Genetic polymorphisms Q192R and L55M account for 8.3 and $4.1 \%$ of interindividual variation in PON1 lactonase activity, respectively, whereas four other SNPs in promoter region, rs854522, rs854534, rs757158, and rs7803148, account for $1.8 \%, 3.8 \%$, $9.2 \%$, and $1.1 \%$ of variability, respectively.

Epigenetics. The main epigenetic mechanisms include DNA methylation, histone modifications, and regulation by noncoding RNAs (ncRNAs) (Berger et al., 2009). Chen et al. (2020) investigated the effect of ncRNA on PON1 lactonase activity. Two ncRNAs were studied in association with PON1, namely long ncRNA Linc-OIP5 and short ncRNA micro-RNA miR-616. It was shown that low levels of LincOIP5 correspond to lower levels of PON1 expression and lactonase activity, whereas high levels of miR-616 gene expression had the opposite effect and decreased PON1 expression and lactonase activity. This difference was demonstrated with high significance in cell culture and in the serum of patients with coronary atherosclerosis.

Proteomics. The activities of PON1 toward lactones, phosphotriesters, and arylesters were suggested to all reside in the same active site (Khersonsky and Tawfik, 2005); however, different changes to PON1 structure might have an uneven effect on different PON1 activities. Hernandez et al. (2009) and Ferretti et al. (2010) investigated the effect of changes in PON1 structure on lactonase activity (Ferretti et al., 2010; Hernandez et al., 2009).

Although heavy metals can corrupt protein structure and irreversibly inhibit activity, different proteins may be differently susceptible to different metals (Josse et al., 2002). Hernandez et al. (2009) investigated this hypothesis by adding different metals in vitro in concentrations that could also be encountered in vivo (e.g., after prolonged exposure) and analyzing PON1 activity in the sera of healthy volunteers. Of the seven metals investigated, only zinc had a statistically significant influence on PON1 lactonase activity, and at the same time lactonase was the only activity affected by addition of zinc. The authors suggest that zinc inhibits PON1 activity by binding to several histidines (His-115, $-134,-155$ and -243 ) that are essential amino acids for the arylesterase and paraoxonase activities of PON1 (Josse et al., 2002).
A similar analysis was carried out investigating the effect of in vitro homocysteinylation of HDL particles, which is known to occur in vivo, on PON1 lactonase activity (Ferretti et al., 2010). The authors demonstrated a decrease in lactonase activity with increasing addition of homocystein thiolactone. The concentrations they used were from 10 to $1000 \mu \mathrm{M}$, and the last of them led to a two-third decrease in lactonase activity compared with the control HDL, where HcyT was absent.

Lipidomics. The lipidomic context of PON1 lactonase activity was investigated with DHC as a substrate in two articles (Rosenblat et al., 2006, 2012).

In the first article, they investigated various enzymatic activities in different lipoprotein fractions of human serum. They analyzed arylesterase, paraoxonase, and lactonase activities, and as expected, no activity was observed in verylow-density lipoprotein (VLDL) and low-density lipoprotein (LDL), whereas all three activities were observed in the HDL fraction. Some enzymatic activity was also observed in the lipoprotein-deficient serum (LPDS) fraction.

Of interest, paraoxonase activity was similar in HDL and LPDS, whereas arylesterase and lactonase activities were significantly higher in HDL compared with LPDS. With lactonase, the difference in activity between HDL and LPDS was greatest. Rosenblat et al. (2006) suggested that the environment in HDL stabilizes PON1's structure; displacement from HDL causes conformational changes that reduce lactonase and arylesterase activity, whereas paraoxonase activity is less sensitive to such changes.

In the second article, Rosenblat et al. (2012) reported the influence of VLDL and free triglycerides on the activity of serum PON1. The authors distinguished PON1 lactonase activity in the total serum and in HDL-bound PON1. The addition of VLDL caused a decrease in HDL-bound PON1 lactonase activity. The authors reported the effect of VLDL with rePON1 as well, which indicates that neighboring proteins and lipids in HDL are not necessary for the mediation of VLDL-induced inhibition. The authors also investigated bezafibrate as a compound, which reverses the effect of VLDL on paraoxonase and arylesterase activity (Rosenblat et al., 2012).

Environmental and social effects on PON1 activity. All the macroscopic, behavioral, and personal parameters with which researchers have attempted to explain interindividual variation in PON1 lactonase activity, such as age, gender, exercise, diet/nutriomics, medications, and exposure to chemicals, were grouped together as "Environmental/Social effects." These factors are also outlined in the second column of Figure 1.

Age. Although the influence of age on PON1 activity in humans is still not entirely clear for adolescents and adults, it has been shown that neonatal PON1 arylesterase activity is much lower than that of toddlers (Cole et al, 2003). For lactonase activity, Gugliucci et al. compared neonatal serum from cord blood with the serum of recent mothers and that of nonpregnant women. Although the difference between the two categories of women was not significant, newborns had on average $23 \%$ and $37 \%$ of the PON1 lactonase and arylesterase activity of their mothers, respectively (Gugliucci et al., 2014). 
In several articles, the authors grouped their results on lactonase activity into categories, including age. An example of such a study is the genome-wide association approach by Quillen et al. (2012), where the authors identified that age accounts for $1.4 \%$ of interindividual variation in PON1 lactonase activity (Quillen et al., 2012).

Gender. Among other factors that influence PON1 activity, Quillen et al. (2012) also focused on the effect of gender on lactonase activity. Although the authors' model indicates that $0.4 \%$ of the interindividual difference in both paraoxonase and arylesterase activities can be explained by gender, we suggest that gender does not appreciably explain interindividual variation in DHC lactonase activity.

A more recent article also focused on the influence of gender on PON1, with TBL as a substrate, and concludes that gender does influence lactonase activity (Trentini et al., 2019). Trentini et al. detected higher PON1 lactonase activity among women than among men, even after accounting for confounders such as concentrations of HDL and cholesterol, age, smoking, body mass index, and waist circumference. The authors reported a significant difference between genders for both lactonase and arylesterase activities (Trentini et al., 2019).

Nutriomics. Unlike medications or body weight, a patient's diet cannot usually be retroactively determined from medical documentation and varies from day to day. When investigating the association between PON1 activity and medical conditions, the influence of diet on enzymatic activity is thus a major potential confounder. One foodstuff, which has been associated with PON1 activity in several articles, is pomegranate. Rock et al. (2008) measured the effect of pomegranate juice on lactonase activity. The authors concluded that pomegranate juice consumption temporarily and significantly increases serum PON1 lactonase activity, both in HDL and LPDS, when both DHC and TBBL were used as substrates. The same increase was also shown with the other substrates (paraoxon and phenylacetate) that the authors tested (Rock et al., 2008).

Aviram and Rosenblat (2012) also investigated how the consumption of several different juices impacts PON1 lactonase activity for DHC. They found that in healthy subjects, consumption of currant juice and pomegranate juice both led to an increase in PON1 lactonase activity after 1 week. Acai, grape juice, and wine however did not significantly impact PON1 activity (Aviram and Rosenblat, 2012).

Kameyama et al. (2016) studied the impact of diet on PON1 lactonase activity. In their study, male volunteers who consumed three different meals and lactonase activity, with TBBL as a substrate, was determined after consumption of these meals. The first meal contained only rice, the second contained rice, fats, and proteins, and the third contained all the above plus vegetables. PON1 lactonase activity was significantly decreased by $5 \%$ in the postprandial period after all test meals. Conversely, arylesterase activity was increased by $10 \%$ in all three groups. However, the type of meal did not influence subsequent lactonase and arylesterase activities. HDL concentration was also measured and did not change significantly in any of the groups during the experiment (Kameyama et al., 2016).
Model organisms have also been used to perform experiments about the impact of diet high in polyunsaturated fatty acids (PUFA) on PON1 lactonase activity. No significant difference in lactonase activity of rat serum before and after a PUFA-rich meal has been demonstrated. Moreover, authors also found no difference in lactonase activity between the nondiabetic control without oil administration and the diabetic group (Kopál et al., 2014).

Medications. Although the interactions of PON1 with various mediations have been established and are displayed in databases such as DrugBank (Wishart et al., 2017), only few of these studies investigated lactonase activity. For example, of the 12 articles focusing on association of PON1 activity and medications for schizophrenia, which were analyzed in a recent review (Moreira et al., 2018), only Gilca et al. (2014) investigated lactonase activity using DHC as a substrate.

Gilca et al. compared lactonase activity in patients taking clozapine, patients taking risperidone, and with healthy individuals. The authors demonstrated that taking risperidone resulted in significantly lower lactonase activity than the healthy control group. The authors also showed that the patients taking clozapine in turn had a significantly lower lactonase activity than the patients taking risperidone. For phenylacetate and paraoxon, the results were exactly the opposite, where highest and lowest enzymatic activity was observed in patients taking risperidone and the control subjects, respectively (Gilca et al., 2014).

Another group of medications, which has been associated with PON1 lactonase activity in one study, are oral contraceptives (Kowalska et al., 2018). The authors concluded that taking contraceptives correlated with a significant increase in lactonase and arylesterase activity, but with a significant decrease in paraoxonase activity.

Chemicals. PON1 is among the few enzymes that offer protection against organophosphate pesticides. LozanoPaniagua et al. (2016) conducted a study in which they addressed the effect of pesticide exposure on PON1 lactonase activity for DHC. The authors concluded that while lactonase activity is not significantly affected by the amount of exposure to pesticides, there is a significant decrease in lactonase activity in greenhouse workers in comparison with the healthy controls with no occupational exposure to pesticides. The authors tested several different organophosphate substrates and reported that higher exposure to pesticides did however lead to a significant decrease in arylesterase activity and, interestingly, to a nonsignificant increase in paraoxonase activity (Lozano-Paniagua et al., 2016).

Exercise. A study followed the effects of an exercise regimen in a group of obese human subjects on the DHC lactonase and paraoxonase activities of their serum PON1 (Russo et al., 2018). After 3 months, both activities increased independent of the subjects' Q192R genotype.

A similar study on rats compared a physically active and a sedentary group (Romani et al., 2009). Both the physically active and the sedentary control group of rats were further subdivided into two groups: exposure vs. no exposure to acute stress. Two lactone substrates, DHC and 2coumaranone, were tested, and for both of them, the results were very similar. A significant increase in PON1 lactonase activity was found in physically active and physically active 
stressed rats with respect to the sedentary and sedentarystressed rats. Significant increase in arylesterase activity was found in physically active rats in comparison with the sedentary, sedentary-stressed, and physically active stressed rats. In contrast, no significant differences were found among the groups of rats when using paraoxon as a substrate (Romani et al., 2009).

\section{Association between PON1 and phenome}

PON1 lactonase activity has been studied regarding several diseases and other medical conditions. Certain medical conditions have been approached in several articles, with the most commonly studied ones being CVD, hepatic illness, obesity, and diabetes. All the conditions discussed hereunder are also listed in the rightmost column of Figure 1. Of the 46 articles listed in Table 1 and discussed in this study, 28 concern themselves with various medical condition that have been associated with PON1 lactonase activity.

Cardiovascular disease. Of all the medical conditions studied in association with PON1 activity, one of the most frequently investigated one is CVD: coronary artery disease and atherosclerosis. Many articles have been published investigating the association of these with PON1, including six articles that included lactonase activity, four of which have been carried out on humans (Gugliucci et al., 2015; Martinelli et al., 2009; Murillo-González et al., 2020; Ponce-Ruiz et al., 2020) and two on animals (De Keyzer et al., 2009; Zhang et al., 2010).

In a study performed on a Mexican population, participants were divided into three groups: (1) healthy controls, (2) a group with chronic renal failure (CRF), which is a risk factor for CVD, and (3) a group with CVD (Murillo-González et al., 2020; Ponce-Ruiz et al., 2020). The authors concluded that DHC lactonase activity was similar between the CRF and CVD groups, and both of which were significantly lower than the lactonase activity of the control group.

In another study, patients with CAD were compared with healthy controls (Martinelli et al., 2009). At first, the difference in TBBL lactonase activity between both groups was nonsignificant. The authors then normalized TBBL activity by dividing it with 7-O-diethyl phosphoryl,3-cyano,4methyl,7-hydroxycoumarin (DEPCyMC) activity, which has been indicated as a surrogate marker for determining PON1 concentration (Gaidukov and Tawfik, 2007).

The resulting normalized lactonase activity was significantly higher in the group with $\mathrm{CAD}$, especially noticeable in individuals with the PON1 192QQ genotype. When they grouped the CAD patients into those with and without myocardial infarction, however, they found no significant difference for any measure of lactonase activity. Other PON1 enzyme activities were not significantly different between any two categories of patients that they compared.

Gugliucci et al. (2015) compared two different ethnic populations, Palestinians and Israelis, and their PON1 enzymatic activities. They found that Palestinians had significantly lower DHC lactonase and arylesterase activities, whereas paraoxonase activity was similar in both populations. From this finding, the authors concluded that the lower lactonase PON1 activity in a Palestinian population is a risk factor for CAD and diabetes.
Another study investigated PON1 activity in apolipoproteindeficient mice expressing human PON1 by adenovirusmediated insertion of human paraoxonase 1 (hPON1) into mice cells (Zhang et al., 2010). The authors investigated the size of atherosclerotic lesions, which are a risk factor for $\mathrm{CVD}$, and found that transgenic mice with overexpressed hPON1 had significantly higher DHC lactonase activity in their serum, and reduced atherosclerotic lesion size.

The PON1-atherosclerosis association has also been investigated in pigs (De Keyzer et al., 2009). The researchers fed a group of pigs with a diet rich in cholesterol and then compared atherosclerosis markers in this group with another group that was fed with a normal diet. As the group fed with a cholesterol-rich diet had both significantly higher PON1 lactonase activity for TBBL and larger atherosclerotic plaques, the authors concluded that PON1 lactonase activity correlates with atherosclerosis.

Hepatic illness. PON1 lactonase activity has also been investigated in association with liver illnesses. In one study, patients with viral hepatitis were compared with those with alcoholic hepatitis and with healthy controls (Mogarekar and Talekar, 2013). It was found that PON1 lactonase activity for DHC was significantly lower in alcoholic hepatitis compared with controls, and being significantly lower in viral hepatitis compared with alcoholic hepatitis. Both significant differences were the same for arylesterase activity.

In another article, the authors investigated TBBL lactonase activity of PON1 in individuals with liver cirrhosis and patients with mild-to-moderate changes in liver function (Marsillach et al., 2009). The authors did not find a statistically significant correlation between enzymatic activities of PON1 and the presence and/or severity of disease.

Serum lactonase activity for DHC was also investigated in dairy cows (Samir Farid et al., 2013). A group with fatty liver was compared with a healthy control group. The authors concluded that paraoxonase, DHC lactonase, and arylesterase activity were all significantly lower in animals with fatty liver compared with the control group.

Obesity. Another factor that has been thoroughly studied in association with PON1 lactonase activity is body weight. Three articles reported on the association between body weight and DHC lactonase activity (Alaminos-Castillo et al., 2019; Bacchetti et al., 2019; Rupérez et al., 2013), Ferré et al. (2013) investigated TBBL and Cervellati et al. (2018) focused on TBL. Of these five articles, three of them found a significant correlation between PON1 lactonase activity and obesity (Alaminos-Castillo et al., 2019; Bacchetti et al., 2019; Ferré et al., 2013).

Alaminos-Castillo et al. (2019) reported that DHC lactonase activity is significantly decreased in obese subjects compared with nonobese controls, and increases after surgery. Bacchetti et al. (2019) grouped cases into two categories, overweight women and obese women, and detected that DHC lactonase activity is significantly decreased in each subsequent category compared with healthy individuals (Bacchetti et al., 2019). Ferré et al. (2013) showed a significant decrease in TBBL lactonase activity in obese children compared with nonobese controls. PON1 concentration was the same in both groups, based on which the authors suggested that in obese children, 
there is higher oxidative stress, which leads to partial inhibition of PON1 by lipid peroxides.

Rupérez et al (2013) did not find an association between PON1 lactonase activity and obesity. Although the authors did not find an association between childhood obesity and any of PON1's enzymatic activities, they did find a positive correlation of DHC lactonase activity with HDL, as well as with concentration of antioxidants. Cervellati et al. (2018) demonstrated a significant decrease in arylesterase activity in very obese subjects; however, they did not show any difference in paraoxonase activity and TBBL lactonase activity between the groups. Hence, the authors concluded that the apparent obesity-associated decrease of PON1 activity might simply reflect the decrease in concentration of HDL.

Diabetes. Five articles reported on PON1 lactonase activity in the context of diabetes (Craciun et al., 2016, Rosenblat et al., 2006, Passaro et al., 2018, Zhou et al., 2020a, 2020b). Four of them focused on diabetic patients themselves (Craciun et al., 2016, Rosenblat et al., 2006, Passaro et al., 2018, Zhou et al., 2020a) and one focused on their children (Zhou et al., 2020b).

In women with gestational diabetes mellitus, no significant difference was found in either TBBL lactonase activity or PON1 concentration between women with diabetes and healthy controls (Zhou et al., 2020a).

For a study on type 1 diabetics, patients were subdivided into two groups based on the level of hemoglobin glycation (Craciun et al., 2016). A significant decrease in $\delta$ valerolactone lactonase activity was noted between controls and patients who had both type 1 diabetes and a high amount of hemoglobin glycation. No difference was found between cases and controls for any other type of PON1 activity (paraoxonase or arylesterase).

DHC lactonase activity was also investigated in a study that compared patients with diabetes, patients with hypercholesterolemia, and healthy controls. The conclusion was that lactonase activity was significantly reduced in both groups of patients, where diabetic patients had the lowest activity. The same results were acquired for both paraoxonase activity and arylesterase activity (Rosenblat et al., 2006).

Passaro et al. compared PON1 activity for TBL in patients with type 2 diabetes and in healthy controls. The authors concluded that there is no correlation between lactonase activity and presence of diabetes, whereas diabetic patients on average had significantly lower arylesterase activity than healthy controls (Passaro et al., 2018).

Zhou et al. compared PON1 lactonase activity for TBBL in neonates with diabetic mothers and in neonates with mothers without diabetes (Zhou et al., 2020b). They found a significant increase in both lactonase activity and DEPCyMCnormalized lactonase activity in children of diabetic patients compared with healthy controls.

Alzheimer's disease. PON1 lactonase activity for DHC was also compared for Alzheimer's disease (AD) patients and healthy controls. The researchers measured lactonase activity and calculated the quotients lactonase activity/HDL concentration and lactonase activity/LDL concentration. For all these, the value was lower for AD patients than for controls. Similarly, decreased values for all three calculations were also acquired for the substrates phenylacetate and paraoxone (Bacchetti et al., 2015).
Other medical conditions. Several other medical conditions were studied in association with PON1 lactonase activity: among them are intestinal cancer, psoriasis, celiac disease, hereditary hemochromatosis, chronic kidney disease (CKD), renal disease, chronic obstructive pulmonary disease (COPB), bronchial asthma, and acute pancreatitis.

Bains et al. (2019) compared PON1 lactonase activity in patients with intestinal cancer before and after treatment. The authors concluded that both arylesterase and DHC lactonase activity significantly decreased after the surgery (compared with before treatment), and then increased again with time (Bains et al., 2019). The researchers also studied the classical inflammatory markers C-reactive protein and serum amyloid A and demonstrated that these changed in exactly the opposite direction, increasing after surgery and then decreasing (Bains et al., 2019).

In psoriatic children, DHC lactonase activity of PON1, as well as arylesterase and paraoxonase activities were found to all be significantly reduced compared with healthy controls (Bacchetti et al., 2020). The authors also measured the concentration of myeloperoxidase (MPO), another enzyme in HDL, which can interact with PON1 and influence its activity. MPO concentration and activity were both significantly decreased and negatively correlated with a decrease in all PON1 enzymatic activities in psoriatic patients.

A significant decrease in PON1 DHC lactonase activity was shown in celiac disease (Ferretti et al., 2012). Lactonase activity was lower in diet-treated patients compared with healthy controls, and even lower in patients at diagnosis, when they had not yet begun their diet. Similar results were obtained for PON1 arylesterase and paraoxonase activities.

In hereditary hemochromatosis, PON1 paraoxonase activity was significantly decreased in patients with the condition compared with healthy controls, but DHC lactonase and arylesterase activities were not decreased significantly (Martinelli et al., 2013). The authors also subdivided patients into those undergoing treatment through phlebotomy and those not undergoing it, and found that none of the PON1 activities correlated with presence of treatment, except for DEPCyMCase activity.

In CKD, a significant decrease in PON1 benzopiran-2-one lactonase activity was reported in cases compared with healthy controls (Mohammed et al., 2019). After adjusting for concentration, the authors showed that lactonase activity was significantly higher in patients compared with non-CKD controls. The authors also compared the groups of CKD patients with high and low lactonase activity in terms of survival rate and reported that patients with higher lactonase activity also had a higher survival rate. No such difference in survival rate was shown when comparing the group with a high PON1 enzyme concentration against the group with a low PON1 concentration.

For end-stage renal patients, a study compared DHC lactonase before and after dialysis and found that activity increases significantly after dialysis, as do arylesterase and paraoxonase activities (Gugliucci et al., 2011). After adjusting for age, gender, and lipid concentration, the increase in activity remained significant.

Patients with severe COPB were compared with those with a mild form and with healthy controls. Both groups of patients had significantly lower TBBL lactonase activities than 
controls. The same trend was present with paraoxonase activity (Soler et al., 2013).

In the case of bronchial asthma, both arylesterase and DHC lactonase PON1 activities were shown to be lower in asthmatics compared with healthy controls (Chen et al., 2018). The authors verified this by addition of PON1 to the serum sample, which resulted in a very significant rise in lactonase activity.

Marek et al. (2018) compared acute pancreatitis patients with healthy controls and further subdivided both groups into smokers and nonsmokers. In both the smoking- and the nonsmoking group, pancreatitis patients had significantly lower PON1 lactonase activity upon admission to hospital than healthy controls. Both the smoking and nonsmoking patients' PON1 lactonase activity significantly declined on both day 3 and day 7 of hospitalization compared with day 1 . When the authors measured PON1 arylesterase activity, they found significantly lower activity in pancreatitis patients compared with healthy controls for both subgroups. For PON1 paraoxonase activity, there was significantly lower activity in pancreatitis patients in comparison with healthy controls, for the nonsmoking subgroups (Marek et al., 2018).

\section{Measurement of serum PON1 lactonase activity}

Different approaches for measuring PON1 lactonase activity do not produce the same results. In addition to the type of substrate that is being used, other factors such as reaction buffers, temperature, and the procedure with which the biological samples are obtained and processed, can also influence the quality of measurement. Ceron et al. (2014) published an extensive and systematic review on measurement of serum PON1 activity, presenting the main reference for PON1 experimental conditions. In their articles, the authors focused on two lactone substrates, TBBL and DHC, two arylesterase substrates, phenyl acetate and 4-nitrophenyl acetate, and paraoxon.

PON1 activity that was reported in the studies cited by the present review was always presented as specific enzyme activity. However, this method of measurement has a

Table 2. Specific Activities of the Human Serum Paraoxonase 1 Toward Dihydrocoumarin, Presented in Different Articles for Groups of Healthy Controls

\begin{tabular}{|c|c|c|c|c|}
\hline & Reference & Title & $\begin{array}{l}\text { Specific activity } \\
(\mathrm{DHC}) \\
{[\mu \mathrm{M} / \mathrm{min} / \mathrm{mL}]}\end{array}$ & $\begin{array}{l}\text { Genotyping } \\
\text { of subjects }\end{array}$ \\
\hline 1 & $\begin{array}{l}\text { Alaminos-Castillo } \\
\text { et al. (2019) }\end{array}$ & $\begin{array}{l}\text { Increased PON lactonase activity in morbidly obese } \\
\text { patients is associated with impaired lipid profile }\end{array}$ & $1.7 \pm 0.5^{\mathrm{a}}$ & No \\
\hline 2 & $\begin{array}{l}\text { Bacchetti et al. } \\
\text { (2015) }\end{array}$ & $\begin{array}{l}\text { Higher levels of oxidized low-density lipoproteins in } \\
\text { Alzheimer's disease patients: Roles for platelet } \\
\text { activating factor acetyl hydrolase and } \\
\text { paraoxonase-1 }\end{array}$ & $26.7 \pm 4.9$ & No \\
\hline 3 & $\begin{array}{l}\text { Bacchetti et al. } \\
\text { (2019) }\end{array}$ & $\begin{array}{l}\text { HDL functionality in follicular fluid in normal } \\
\text { weight and obese women undergoing assisted } \\
\text { reproductive treatment }\end{array}$ & $6.9 \pm 0.3$ & No \\
\hline 4 & $\begin{array}{l}\text { Bacchetti et al. } \\
\text { (2020) }\end{array}$ & $\begin{array}{l}\text { Plasma oxidation status and antioxidant capacity in } \\
\text { psoriatic children }\end{array}$ & $27.2 \pm 1.4$ & No \\
\hline 5 & Bains et al. (2019) & $\begin{array}{l}\text { Paraoxonase 1, HDL subclasses and postsurgery } \\
\text { acute inflammation: A pilot study }\end{array}$ & $42 \pm 9^{\mathrm{a}}$ & No \\
\hline 6 & Ferretti et al. (2012) & $\begin{array}{l}\text { Lipid peroxidation and paraoxonase- } 1 \text { activity in } \\
\text { celiac disease }\end{array}$ & $68(32-184)$ & No \\
\hline 7 & Gilca et al. (2014) & $\begin{array}{l}\text { A study of antioxidant activity in patients with } \\
\text { schizophrenia taking atypical antipsychotics }\end{array}$ & $57.27 \pm 1.34$ & No \\
\hline 8 & $\begin{array}{l}\text { Gugliucci et al. } \\
\text { (2014) }\end{array}$ & $\begin{array}{l}\text { Paraoxonase } 1 \text { lactonase activity and distribution in } \\
\text { the HDL subclasses in the cord blood }\end{array}$ & $60.3 \pm 20.2$ & No \\
\hline 9 & $\begin{array}{l}\text { Gugliucci et al. } \\
\text { (2015) }\end{array}$ & $\begin{array}{l}\text { Low protective PON1 lactonase activity in an Arab } \\
\text { population with high rates of coronary heart } \\
\text { disease and diabetes A }\end{array}$ & $\begin{array}{c}10.4 \pm 3.2 \\
\text { (Palestinians), } \\
11.7 \pm 3.6 \text { (Israelis) }\end{array}$ & Yes \\
\hline 10 & $\begin{array}{l}\text { Kowalska et al. } \\
\text { (2018) }\end{array}$ & $\begin{array}{l}\text { Influence of oral contraceptives on lipid profile and } \\
\text { paraoxonase and commonly hepatic enzymes } \\
\text { activities }\end{array}$ & 9.2 & No \\
\hline 11 & $\begin{array}{l}\text { Lozano-Paniagua } \\
\text { et al. (2016) }\end{array}$ & $\begin{array}{l}\text { Activity and determinants of cholinesterases and } \\
\text { paraoxonase- } 1 \text { in blood of workers exposed to } \\
\text { noncholinesterase inhibiting pesticides }\end{array}$ & $14.4 \pm 0.4$ & Yes \\
\hline 12 & Marek et al. (2018) & $\begin{array}{l}\text { Decreases in paraoxonase- } 1 \text { activities promote a } \\
\text { proinflammatory effect of lipids peroxidation } \\
\text { products in nonsmoking and smoking patients } \\
\text { with acute pancreatitis }\end{array}$ & $9^{a}$ & No \\
\hline 13 & $\begin{array}{l}\text { Mogarekar and } \\
\text { Talekar (2013) }\end{array}$ & $\begin{array}{l}\text { Serum lactonase and arylesterase activities in } \\
\text { alcoholic hepatitis and hepatitis B }\end{array}$ & $13.3 \pm 4.1$ & No \\
\hline 14 & $\begin{array}{l}\text { Murillo-González } \\
\text { et al. (2020) }\end{array}$ & $\begin{array}{l}\text { PON1 lactonase activity and its association with } \\
\text { cardiovascular disease }\end{array}$ & $13^{\mathrm{a}}$ & Yes \\
\hline
\end{tabular}

${ }^{\mathrm{a}}$ The numerical value was obtained from a graph. 
Table 3. Specific Activities of the Human Serum Paraoxonase 1 Toward Thiobutyl Butyrolactone, Presented in Different Articles for Groups of Healthy Controls

\begin{tabular}{|c|c|c|c|c|}
\hline & Reference & Title & $\begin{array}{l}\text { Specific activity } \\
\quad(T B B L) \\
{[\mu M / \mathrm{min} / \mathrm{mL}]}\end{array}$ & $\begin{array}{l}\text { Genotyping } \\
\text { of subjects }\end{array}$ \\
\hline 1 & $\begin{array}{l}\text { Ferré } \\
\quad \text { et al. (2013) }\end{array}$ & $\begin{array}{l}\text { Impaired paraoxonase-1 status in obese children. Relationships } \\
\text { with insulin resistance and metabolic syndrome }\end{array}$ & $7.3(3.4-12.12)$ & Yes \\
\hline 2 & $\begin{array}{l}\text { Gaidukov and } \\
\text { Tawfik (2007) }\end{array}$ & $\begin{array}{l}\text { The development of human sera tests for HDL-bound serum } \\
\text { PON1 and its lipolactonase activity }\end{array}$ & $3.8 \pm 1.9$ & No \\
\hline 3 & $\begin{array}{l}\text { Kameyama } \\
\text { et al. }(2016)\end{array}$ & $\begin{array}{l}\text { Postprandial paraoxonase } 1 \text { activity after consumption of } \\
\text { recommended amounts of mixed meals in healthy men }\end{array}$ & $75 \pm 21$ & Yes \\
\hline 4 & $\begin{array}{l}\text { Marsillach } \\
\text { et al. (2009) }\end{array}$ & $\begin{array}{l}\text { The measurement of the lactonase activity of paraoxonase- } 1 \text { in } \\
\text { the clinical evaluation of patients with chronic liver } \\
\text { impairment }\end{array}$ & $\begin{array}{c}5.99 \\
(3.29-13.61)\end{array}$ & Yes \\
\hline 5 & $\begin{array}{l}\text { Martinelli } \\
\text { et al. (2009) }\end{array}$ & $\begin{array}{l}\text { Novel serum paraoxonase activity assays are associated with } \\
\text { coronary artery disease }\end{array}$ & $3.37 \pm 1.10$ & Yes \\
\hline 6 & $\begin{array}{l}\text { Martinelli } \\
\quad \text { et al. (2012) }\end{array}$ & $\begin{array}{l}\text { Low levels of serum paraoxonase activities are characteristic of } \\
\text { metabolic syndrome and may influence the metabolic- } \\
\text { syndrome-related risk of coronary artery disease }\end{array}$ & $3.45 \pm 0.98$ & Yes \\
\hline 7 & $\begin{array}{l}\text { Martinelli } \\
\text { et al. (2013) }\end{array}$ & $\begin{array}{l}\text { Paraoxonase-1 status in patients with hereditary } \\
\text { hemochromatosis }\end{array}$ & $5.9(3.5-8.9)$ & Yes \\
\hline 8 & $\begin{array}{l}\text { Soler } \\
\quad \text { et al. (2013) }\end{array}$ & $\begin{array}{l}\text { Paraoxonase-1 is associated with corneal endothelial cell } \\
\text { alterations in patients with chronic obstructive pulmonary } \\
\text { disease }\end{array}$ & $7.0(3.2-11.0)$ & Yes \\
\hline
\end{tabular}

drawback. It is not clear whether the difference in serum enzyme activity is because of a difference in the concentration of the enzyme or because of a difference in its activity.

To distinguish the effect of concentration from enzyme activity, kinetic parameters can be determined alongside specific activity. Among these kinetic parameters are Michaelis constant $\mathrm{K}_{\mathrm{m}}$, which is independent of substrate concentration and defines the affinity of the enzyme for the substrate, and $\mathrm{V}_{\max }$, the reaction rate at the maximum substrate concentration. The classical method of determining $\mathrm{K}_{\mathrm{m}}$, which is still widely used today, is carried out by determining the initial rates of product formation at different substrate concentrations. This process is time- and material consuming and certain kinetic parameters are not accurate.

A more recent approach is to determine $\mathrm{K}_{\mathrm{m}}$ and $\mathrm{V}_{\max }$ from progressive curves, to which the parameters of the model function are fitted (Goličnik and Bavec, 2020). The advantage of this approach over the method of determining the initial velocities is that less biological sample is consumed and that the results are more accurate. The shortcomings in the determination of specific enzyme activities in the articles are likely also among the reasons for the relatively large differences between the results in Tables 2 and 3 described hereunder.

For both the common lactone substrates, DHC and TBBL, we present the specific activities measured in each article for healthy human controls (Tables 2 and 3). To assist in clarity, we omitted articles that do not have an obvious healthy control group (i.e. only compare two groups of patients), were not performed on humans, or did not present their results in the standard units of $\mu \mathrm{M}$ of substrate $/ \mathrm{min} / \mathrm{mL}$ of serum (i.e., $\mathrm{U} / \mathrm{mL}$ ).

It is apparent that the results in Tables 2 and 3 differ considerably between groups, although the interindividual activity measured by a specific group is often small. It is beyond the scope of this article to attempt to fully explain these differences. Part of them might be influenced by the differences in ethnic composition of the populations inves- tigated, as suggested by at least one of the articles we discussed (Gugliucci et al., 2015). They might also be influenced by the different temperatures used for measurement in specific experiments (a range from $25^{\circ} \mathrm{C}$ to $37^{\circ} \mathrm{C}$ ).

Few studies provide a breakdown by genotype, but the different genetic compositions of world populations are unlikely to explain the large diversity of results in Tables 2 and 3. Billecke et al. (2000) compared the specific activities of human PON1 isoforms Q and R for DHC and found a difference of $<20 \%$ between these two isoforms, whereas the difference between the highest and the lowest observed specific activity in Table 2 of this article is more than an order of magnitude.

The only common known factor that can cause such large differences between specific activities is the presence or absence of ethylenediaminetetraacetic acid (EDTA) in blood/ serum. EDTA binds calcium, which is a cofactor of PON1, and thus irreversibly inhibits the enzyme. Although several recommendations against using EDTA have been published in literature (e.g., Mackness, 1998), it is sometimes not possible to avoid contamination. Among the articles in the charts hereunder, two groups admitted using tubes with EDTA for collecting blood (Ponce-Ruiz et al., 2020; Soler et al., 2013).

Most articles do not state which tubes had been used for blood collection, which leaves open the possibility that EDTA was used in several other studies. Among the researchers working on DHC, Gilca et al. (2014) and Kowalska et al. (2018), reported an average specific activity for healthy controls of 57.3 and $9.2 \mathrm{U} / \mathrm{mL}$, respectively. Kowalska et al. claimed to have used only heparin tubes for blood collection. Hence, EDTA, by itself cannot explain the entire range of differences that was observed between articles.

\section{Conclusions and Future Directions}

Paraoxonase activity, with the eponymous substrate, and arylesterase activity, with phenlyacetate as a substrate, had 
been used to characterize serum PON1 since the 1980s. Lactonase activity measurements only began to be used in the mid-2000s, after a series of articles, which suggested that lactonase is the native activity of PON1 and which launched several promising artificial lactone substrates of PON1 (Khersonsky and Tawfik, 2006).

Measuring PON1 lactonase activity has always been sidelined by paraoxonase and arylesterase activities. For example, Zhao et al. (2012) conducted a meta-analysis in which they gathered 43 studies investigating the association between serum PON1 activity and risk of CVD. All the studies in question included at least one substrate for paraoxonase activity and at least one for arylesterase activity; however, the authors of the meta-analysis could not find a single study in which a lactone substrate would be tested.

The association between PON1 activity and disease is most often based on the determination of a single activity. Such interpretations of the results can lead to erroneous diagnostic predictions. For example, in a human study comparing paraoxon, phenyl acetate and 4-nitrophenyl acetate, only 4nitrophenylacetate showed significant changes between patients with CRF and healthy individuals (Dantoine et al., 1998). In another study, TBBL was found to be more sensitive in identifying an association between decreased serum PON1 activity and metabolic syndrome in childhood obesity than paraoxon (Ferré et al., 2013).

Based on our analysis of the published literature, we proposed the following guidelines for the development of the research field.

(1) It is recommended to determine two or three activities with different substrates, instead of just one activity with one substrate. Clinical researchers should also include measurements of lactonase activity in future PON1 studies, and studies carried out before 2000 would benefit from a remake with lactone substrate participation.

(2) Researchers should be advised to keep the distinction between affinity for substrate, as measured by $\mathrm{K}_{\mathrm{m}}$, and enzyme concentration in mind when designing experiments.

(3) Researchers focusing on PON1 lactonase activity in humans are advised to conduct genotyping as well.

(4) When investigating the association of PON1 lactonase activity, and other PON1 activities, with specific medical conditions, it is advisable to account for other comorbidities, especially the ones that have been associated with PON1 lactonase activity.

(5) More generally, the different multi-omics factors that can influence PON1 lactonase activity should be kept in mind by researchers. Potential confounding factors, both biological and environmental/social, should be accounted for when designing experiments.

This study contributes to better understanding of the associations among all three PON1 enzyme activities and different diseases/conditions while highlighting the importance of measuring lactonase activity in clinical studies.

\section{Author Disclosure Statement}

The authors declare they have conflicting financial interests.

\section{Funding Information}

This research was supported by the Slovenian Research Agency (Grant No. P1-170).

\section{References}

Aharoni A, Gaidukov L, Yagur S, et al. (2004). Directed evolution of mammalian paraoxonases PON1 and PON3 for bacterial expression and catalytic specialization. Proc Natl Acad Sci U S A 101, 482-487.

Alaminos-Castillo M, Ho-Plagaro A, García-Serrano S, et al. (2019). Increased PON lactonase activity in morbidly obese patients is associated with impaired lipid profile. Int J Clin Pract 73,e13315.

Aviram M, and Rosenblat M. (2012). Pomegranate protection against cardiovascular diseases. Evid Based Complement Alternat Med 2012, 382763

Bacchetti T, Morresi C, Vignini A, et al. (2019). HDL functionality in follicular fluid in normal-weight and obese women undergoing assisted reproductive treatment. J Assist Reprod Genet 36, 1657-1664.

Bacchetti T, Simonetti O, Ricotti F, Offidani A, and Ferretti G. (2020). Plasma oxidation status and antioxidant capacity in psoriatic children. Arch Dermatol Res 312, 33-39.

Bacchetti T, Vignini A, Giulietti A, et al. (2015). Higher levels of oxidized low density lipoproteins in Alzheimer's disease patients: Roles for platelet activating factor acetyl hydrolase and paraoxonase-1. J Alzheimers Dis 46, 179-186.

Berger SL, Kouzarides T, Shiekhattar R, and Shilatifard A. (2009). An operational definition of epigenetics. Genes Dev 23, 781-783.

Bains Y, Caccavello R, Kotani K, and Gugliucci A. (2019). Paraoxonase 1, HDL subclasses and post surgery acute inflammation: A pilot study. Antioxidants (Basel) 8, 192.

Billecke S, Draganov D, Counsell R, et al. (2000). Human serum paraoxonase (PON1) isozymes $\mathrm{Q}$ and $\mathrm{R}$ hydrolyze lactones and cyclic carbonate esters. Drug Metab Dispos 28, 1335-1342.

Ceron JJ, Tecles F, and Tvarijonaviciute A. (2014). Serum paraoxonase 1 (PON1) measurement: An update. BMC Vet Res 10, 74.

Cervellati C, Bonaccorsi G, Trentini A, et al. (2018). Paraoxonase, arylesterase and lactonase activities of paraoxonase1 (PON1) in obese and severely obese women. Scand J Clin Lab Invest 78, 18-24.

Chen H, Song X, Wu Y, et al. (2020). Linc-OIP5 working as a ceRNA of miR-616 promotes PON1 expression in HUEVC cells. Int J Clin Exp Pathol 13, 730-737

Chen WQ, Xie ZZ, Wang X, Zhao J, Hu Q, et al. (2018). Influences of PON1 on airway inflammation and remodeling in bronchial asthma. J Cell Biochem 119, 793-805.

Cole TB, Jampsa RL, Walter BJ, Arndt TL, Richteret RJ, et al. (2003). Expression of human paraoxonase (PON1) during development. Pharmacogenetics 13, 357-364.

Costa LG, Vitalone A, Cole T, and Furlong CE. (2005). Modulation of paraoxonase (PON1) activity. Biochem Pharmacol $69,541-550$.

Craciun EC, Leucuta DC, Rusu RL, David BA, Cret V, et al. (2016). Paraoxonase-1 activities in children and adolescents with type 1 diabetes mellitus. Acta Biochim Pol 63, 511-515.

Dantoine TF, Debord J, Charmes JP, Merle L, Marquet P, et al. (1998). Decrease of serum paraoxonase activity in chronic renal failure. J Am Soc Nephrol 9, 2082-2088.

Dardiotis E, Aloizou AM, Siokas V, Tsouris Z, Rikos D, et al. (2019). Paraoxonase-1 genetic polymorphisms in organophosphate metabolism. Toxicology 411, 24-31.

Darney K, Kasteel EEJ, Buratti FM, Turco L, Vichi S, et al. (2020). Bayesian meta-analysis of inter-phenotypic di ff erences in human serum paraoxonase- 1 activity for chemical risk assessment. Environ Int 138, 105609. 
De Keyzer D, Karabina SA, Wei W, Geeraert B, Stengel D, et al. (2009). Increased PAFAH and oxidized lipids are associated with inflammation and atherosclerosis in hypercholesterolemic pigs. Arterioscler Thromb Vasc Biol 29, 2041-2046.

Farid AS, Honkawa K, Fath EM, Nonaka N, and Horii Y. (2013). Serum paraoxonase-1 as biomarker for improved diagnosis of fatty liver in dairy cows. BMC Vet Res 9, 73.

Ferré N, Feliu A, García-Heredia A, Marsillach J, París N, et al. (2013) Impaired paraoxonase-1 status in obese children. Relationships with insulin resistance and metabolic syndrome. Clin Biochem 46, 1830-1836.

Ferretti G, Bacchetti T, Masciangelo S, and Bicchiega V. (2010). Effect of homocysteinylation on high density lipoprotein physico-chemical properties. Chem Phys Lipids 163, 228-235.

Ferretti G, Bacchetti T, Saturni L, Manzella N, Candelaresi C, et al. (2012). Lipid peroxidation and paraoxonase-1 activity in celiac disease. J Lipids 2012, 587479.

Gaidukov L, and Tawfik DS. (2007). The development of human sera tests for HDL-bound serum PON1 and its lipolactonase activity. J Lipid Res 48, 1637-1646.

Gilca M, Piriu G, Gaman L, Delia C, Iosif L, et al. (2014). A study of antioxidant activity in patients with schizophrenia taking atypical antipsychotics. Psychopharmacology 231, 4703-4710.

Goličnik M, and Bavec A. (2020). Evaluation of the paraoxonase-1 kinetic parameters of the lactonase activity by nonlinear fit of progress curves. J Enzyme Inhib Med Chem 35, 261-264.

Gugliucci A, Caccavello R, Nassar H, Ahmad WA, Sinnreich R, et al. (2015). Low protective PON1 lactonase activity in an Arab population with high rates of coronary heart disease and diabetes. Clin Chim Acta 445, 41-47.

Gugliucci A, Kinugasa E, Kotani K, Caccavello R, and Kimura S. (2011). Serum paraoxonase 1 (PON1) lactonase activity is lower in end-stage renal disease patients than in healthy control subjects and increases after hemodialysis. Clin Chem Lab Med 49, 61-67.

Gugliucci A, Numaguchi M, Caccavello R, and Kimura S. (2014). Paraoxonase 1 lactonase activity and distribution in the HDL subclasses in the cord blood. Redox Report 19, 124-132.

Harel M, Aharoni A, Gaidukov L, Brumshtein B, Khersonsky O, et al. (2004). Structure and evolution of the serum paraoxonase family of detoxifying and anti-atherosclerotic enzymes. Nat Struct Mol Biol 11, 412-419

Hernandez A, Gil F, Leno E, Lo O, Rodrigo L, Pla A, et al. (2009). Interaction between human serum esterases and environmental metal compounds. Neurotoxicology 30, 628-635

Josse D, Masson P, Bartels C, and Lockridge O. (2002). PON1 structure. In Costa LG, and Furlong CE (eds): Paraoxonase (PON1) in Health and Disease. Kluwer Academic Publishers, Boston, Massachusetts, 27-52.

Kameyama N, Maruyama C, Kotani K, Caccavello R, Gugliucci A, et al. (2016). Postprandial paraoxonase 1 activity following consumption of recommended amounts of mixed meals in healthy males. J Atheroscler Thromb 23, 225-232.

Khersonsky O, and Tawfik DS. (2005). Structure-reactivity studies of serum paraoxonase PON1 suggest that its native activity is lactonase. Biochemistry 44, 6371-6382.

Khersonsky O, and Tawfik DS. (2006). Chromogenic and fluorogenic assays for the lactonase activity of serum paraoxonases. Chembiochem 7, 49-53.
Kopál M, Ondrejovičová I, Deáková Z, Uličná O, Vančová O, et al. (2014). Effect of PUFA-rich plant oil on risk factors of STZinduced diabetes in Wistar rats. Redox Report 19, 161-169.

Kowalska K, Ściskalska M, Bizoń A, Śliwińska-Mossoń M, and Milnerowicz H. (2018). Influence of oral contraceptives on lipid profile and paraoxonase and commonly hepatic enzymes activities. J Clin Lab Anal 32, e22194.

Lozano-Paniagua D, Gómez-Martín A, Gil F, Parrón T, Alarcón $\mathrm{R}$, et al.(2016). Activity and determinants of cholinesterases and paraoxonase-1 in blood of workers exposed to noncholinesterase inhibiting pesticides. Chem Biol Interact 259, 160-167.

Mackness MI. (1998). Human serum paraoxonase is inhibited in EDTA plasma. Biochem Biophys Res Commun $242,249$.

Mackness M, and Mackness B. (2015). Human paraoxonase-1 (PON1): Gene structure and expression, promiscuous activities and multiple physiological roles. Gene 567, 12-21.

Marek G, Ściskalska M, Grzebieniak Z, and Milnerowicz H. (2018). Decreases in paraoxonase- 1 activities promote a proinflammatory effect of lipids peroxidation products in nonsmoking and smoking patients with acute pancreatitis. Int J Med Sci 15, 1619-1630.

Marsillach J, Aragonès G, Beltrán R, Caballeria J, Pedro-Botet J, et al. (2009). The measurement of the lactonase activity of paraoxonase-1 in the clinical evaluation of patients with chronic liver impairment. Clin Biochem 42, 91-98.

Martinelli N, García-Heredia A, Roca H, et al. (2013). Paraoxonase-1 status in patients with hereditary hemochromatosis. J Lipid Res 54, 1484-1492.

Martinelli N, Girelli D, Olivieri O, et al. (2009). Novel serum paraoxonase activity assays are associated with coronary artery disease. Clin Chem Lab Med 47, 432-440.

Martinelli N, Micaglio R, Consoli L, Guardini P, Grison E, et al. (2012). Low levels of serum paraoxonase activities are characteristic of metabolic syndrome and may influence the metabolic syndrome-related risk of coronary artery disease. Exp Diabetes Res 2012, 231502. DOI: 10.1155/2012/231502.

Metcalf JS, and Bruno M. (2016). Anatoxin-a(S). In Meriluoto J, Spoof L, and Codd GA (eds): Handbook of Cyanobacterial Monitoring and Cyanotoxin Analysis. John Wiley \& Sons, Ltd, Hoboken, New Jersey, 155-159.

Mogarekar MR, and Talekar SJ. (2013). Serum lactonase and arylesterase activities in alcoholic hepatitis and hepatitis B. Indian J Gastroenterol 32, 307-310.

Mohammed CJ, Xie Y, Brewster PS, Ghosh S, Dube P, et al. (2019). Circulating lactonase activity but not protein level of PON-1 predicts adverse outcomes in subjects with chronic kidney disease. J Clin Med 8, 1034.

Moreira EG, Boll KM, Correia DG, Soares JF, Rigobello C, et al. (2018). Why should psychiatrists and neuroscientists worry about paraoxonase 1?. Curr Neuropharmacol 17, 10041020.

Murillo-González FE, Ponce-Ruiz N, Rojas-García AE, Rothenberg SJ, Bernal-Hernández YY, et al. (2020). PON1 lactonase activity and its association with cardiovascular disease. Clin Chim Acta 500, 47-53.

Passaro A, Vigna GB, Romani A, Sanz JM, Cavicchio C, et al. (2018). Distribution of paraoxonase-1 (PON-1) and lipoprotein phospholipase A2 (Lp-PLA2) across lipoprotein subclasses in subjects with type 2 diabetes. Oxid Med Cell Longev 2018, 1752940.

Pirih N, and Kunej T. (2017). Toward a taxonomy for multiomics science? Terminology development for whole genome 
study approaches by omics technology and hierarchy. OMICS $21,1-16$.

Ponce-Ruiz N, Murillo-González FE, Rojas-García AE, Bernal Hernández YY, Mackness M, et al. (2020). Phenotypes and concentration of PON1 in cardiovascular disease: The role of nutrient intake. Nutr Metab Cardiovasc Dis 30, 40-48.

Quillen EE, Rainwater DL, Dyer TD, Carless MA, Curran JE, et al. (2012). Novel associations of nonstructural loci with paraoxonase activity. J Lipids 2012, 189681.

Rainwater DL, Rutherford S, Dyer TD, Rainwater ED, Cole SA, et al. (2009). Determinants of variation in human serum paraoxonase activity. Heredity 102, 147-154.

Rock W, Rosenblat M, Miller-Lotan R, Levy AP, Elias M, et al. (2008) Consumption of Wonderful variety pomegranate juice and extract by diabetic patients increases paraoxonase 1 association with high-density lipoprotein and stimulates its catalytic activities. J Agric Food Chem 56, 8704-8713.

Romani R, De Medio GE, Di Tullio S, Lapalombella R, Pirisinu I, et al. (2009). Modulation of paraoxonase 1 and 3 expression after moderate exercise training in the rat. J Lipid Res 50, 2036-2045.

Rosenblat M, Karry R, and Aviram M. (2006). Paraoxonase 1 (PON1) is a more potent antioxidant and stimulant of macrophage cholesterol efflux, when present in HDL than in lipoprotein-deficient serum: Relevance to diabetes. Atherosclerosis 187, 74.e1-e74.e10.

Rosenblat M, Ward S, Volkova N, Hayek T, and Aviram M. (2012). VLDL triglycerides inhibit HDL-associated paraoxonase 1 (PON1) activity: In vitro and in vivo studies. Biofactors 38, 292-299.

Rupérez AI, López-Guarnido O, Gil F, Olza J, Gil-Campos M, et al. (2013). Paraoxonase 1 activities and genetic variation in childhood obesity. Br J Nutr 110, 1639-1647.

Russo A, Pirisinu I, Vacca C, Reginato E, Tomaro ES, et al. (2018). An intensive lifestyle intervention reduces circulating oxidised low-density lipoprotein and increases human paraoxonase activity in obese subjects. Obes Res Clin Pract 12, $108-114$.

Shunmoogam N, Naidoo P, and Chilton R. (2018). Paraoxonase (PON)-1: A brief overview on genetics, structure, polymorphisms and clinical relevance. Vasc Health Risk Manag 14, 137-143.

Soler N, García-Heredia A, Marsillach J, Mackness B, Mackness M, et al. (2013). Paraoxonase-1 is associated with corneal endothelial cell alterations in patients with chronic obstructive pulmonary disease. Invest Ophthalmol Vis Sci 54, 5852-5858.

Trentini A, Bellini T, Bonaccorsi G, Cavicchio C, Hanau S, Passaro A, et al. (2019). Sex difference: An important issue to consider in epidemiological and clinical studies dealing with serum paraoxonase-1. J Clin Biochem Nutr 64, 250-256.

Wishart D, Djoumbou Y, Guo AC, Lo E, Marcu A, et al. (2017). DrugBank 5.0: A major update to the DrugBank database for 2018. Nucleic Acids Research 46, D1074-D1082.
Zhang C, Peng W, Wang M, Zhu J, Zang Y, et al. (2010). Studies on protective effects of human paraoxonases 1 and 3 on atherosclerosis in apolipoprotein E knockout mice. Gene Ther 17, 626-633.

Zhao Y, Ma Y, Fang Y, Liu L, Wu S, et al. (2012). Association between PON1 activity and coronary heart disease risk: A meta-analysis based on 43 studies. Mol Genet Metab 105, 141-148.

Zhou M, Liu XH, Liu QQ, et al. (2020a). Lactonase activity, status, and genetic variations of paraoxonase 1 in women with gestational diabetes mellitus. J Diabetes Res 2020, 3483427.

Zhou M, Liu XH, Liu QQ, et al. (2020b). Lactonase activity and status of paraoxonase 1 and oxidative stress in neonates of women with gestational diabetes mellitus. Pediatr Res [Epub ahead of print]; DOI 1038/s41390-020-1023-2

Address correspondence to: Aljoša Bavec, PhD Faculty of Medicine Institute of Biochemistry University of Ljubljana Vrazov trg 2

Ljubljana SI-1000

Slovenia

E-mail: aljosa.bavec@mf.uni-lj.si

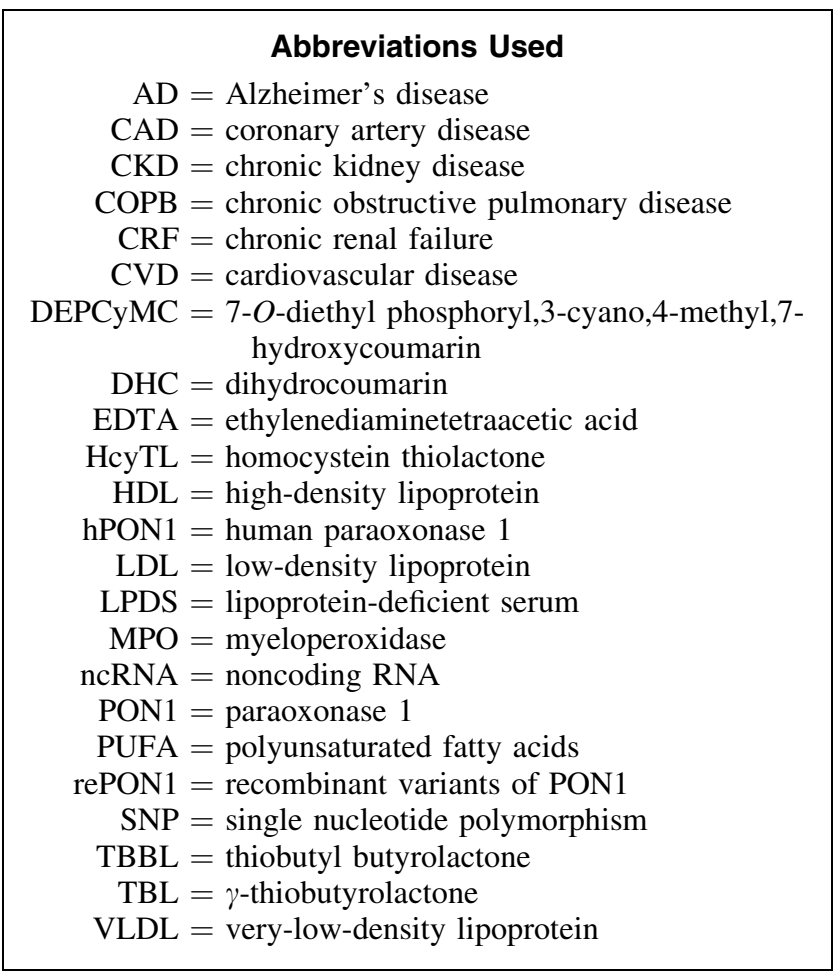

